\title{
Effect of Specimen Dimensions on Yield Shear Stress in Torsion Testing by using Taguchi Method and GRA
}

\author{
Rajkumar D. Patil, Purushottam N. Gore
}

\begin{abstract}
In this paper, investigated the effect of Al 6061 T6 solid specimen dimensions on torsional tests on yield shear stress. Torsion experiments were conducted at various levels of solid aluminum samples using key sample dimensions such as outer diameter, effective length, total length and fillet radius. Taguchi parameter design and optimization approaches are used to design experiments, and then predict the optimal set of parameters. Multi-objective optimization was done using the Grey Relational Analysis (GRA) method. In the GRA method, a grey relational grade is found to determine a set of parameters for multi-objective optimization of parameters. It is found that the outer diameter has a greater effect on the yield shear stress.
\end{abstract}

Keywords: Yield shear stress, Taguchi, ANOVA and GRA.

\section{INTRODUCTION}

The shear properties of engineering materials are evaluated using torsion test experiments. It is important to know if the material is strong and rigid enough to withstand the shear loads it receives during use [1]. In designing, and analyzing, the shear stress-strain response of materials subjected to shear or torsional loads is very important. These shear properties are determined from the shear stress-strain diagram and measured according to the ASTM A 938-07 torsion test [2]. An experimental study under various types of stress conditions was conducted to establish a fracture criterion. Construction of fracture surface shear tests for thin-walled tubular specimens of different shapes must be carried out [3]. The torsion can also be applied to determine the forging capacity of a material at high temperatures. The Nadia method was used to compute the shear stress - strain for the torsion test results [4]. In this study, a torsion test is performed on an Al 6061 T6 solid specimen using a 200 Nm digital torsion tester. Recognizing important parameters and predicting the optimal settings for each process parameter is also an important tool. Taguchi parameter technology is a single parameter optimization grounded on the signal-to-noise ratio [12] . GRA is widely used in experimental designs related to various machining processes

Revised Manuscript Received on October 30, 2019.

* Correspondence Author

Prof. Rajkumar D. Patil*, assistant professor in D.K.T.E.'s Textile and Engineering Institute, Ichalkaranji, Maharashtra-416115, India.

Prof. Purushottam N. Gore, Associate Professor in Mechanical Engineering department of D.K.T.E.'s Textile and Engineering Institute, Ichalkaranji, Maharashtra-416115, India.

(C) The Authors. Published by Blue Eyes Intelligence Engineering and Sciences Publication (BEIESP). This is an open access article under the CC BY-NC-ND license (http://creativecommons.org/licenses/by-nc-nd/4.0/)
[5-10]. The Gray Relational Grade (GRG) method is used for multi-objective optimization and analysis of variance (ANOVA) to find the most important parameters [11].

\section{DESIGN OF EXPERIMENTS}

The material selected for the current study was aluminum grade 6061 T6. Table I shows the chemical composition of aluminum 6061 T6. T6 means solution heat treatment and artificially aged. Physical and Mechanical properties are shown in table II.

Table- I: Aluminium (6061 T6) Chemical composition [3]

\begin{tabular}{|c|c|c|c|c|c|c|c|c|}
\hline Element & $\mathrm{Cu}$ & $\mathrm{Pb}$ & $\mathrm{Bi}$ & $\mathrm{Iron}$ & $\mathrm{Si}$ & $\mathrm{Zn}$ & & \\
\hline $\mathbf{( \% )}$ & $5-$ & 0.2 & 0.2 & $0.0-$ & 0.0 & 0.0 & $0.0-$ & $\mathrm{Bal}$ \\
& 6 & - & - & 0.7 & - & - & 0.15 & \\
\hline
\end{tabular}

Table- II: Physical and Mechanical properties of Aluminium (6061 T6) [3]

\begin{tabular}{|c|c|c|c|}
\hline $\begin{array}{c}\text { Sr. } \\
\text { No. }\end{array}$ & Property & Value & Units \\
\hline 1 & Maximum stress & 310 & $\mathrm{~N} / \mathrm{mm}^{2}$ \\
\hline 2 & Yield Stress & $275 \mathrm{~min}$. & $\mathrm{N} / \mathrm{mm}^{2}$ \\
\hline 3 & $0.2 \%$ proof stress & $230 \mathrm{~min}$. & $\mathrm{N} / \mathrm{mm}^{2}$ \\
\hline 4 & Poisson's ratio & 0.33 & $\mathrm{~N} / \mathrm{A}$ \\
\hline 5 & Shear modulus in XY & 26000 & $\mathrm{~N} / \mathrm{mm}^{2}$ \\
\hline 6 & Mass density & 2700 & $\mathrm{Kg} / \mathrm{m}^{3}$ \\
\hline
\end{tabular}

Taguchi method was used to design the experiment. Orthogonal arrays were used to reduce the number of experiments performed during full factorial experiments. Based on specimen strength and ASTM A938-07, the specimen dimensions and levels are shown in Table III.

Table-III: Solid Al sample dimensions and levels [10]

\begin{tabular}{|c|c|c|c|c|}
\hline $\begin{array}{c}\text { Sr. } \\
\text { no }\end{array}$ & $\begin{array}{c}\text { Specimen dimensions } \\
(\mathbf{m m})\end{array}$ & Level I & Level II & Level III \\
\hline 1. & Total length & 203.0 & 162.0 & 130.0 \\
\hline 2. & Useful length & 78.0 & 62.4 & 50.0 \\
\hline 3. & Outer diameter & 10.0 & 8.0 & 6.0 \\
\hline 4. & Fillet radius & 3.0 & 2.5 & 2.0 \\
\hline
\end{tabular}


The control factor is 4 and the level is 3 . Therefore, the degree of freedom is $4(3-1)=8$. L9 OA is selected because the number of OA experiments must be greater than the degree of freedom. Table IV shows the required combinations of input parameters using L9 orthogonal arrays.

Table- IV: Solid Al Taguchi L9 Standard Orthogonal Array Design Matrix [27]

\begin{tabular}{|c|c|c|c|c|}
\hline $\begin{array}{l}\underset{\mathrm{s}}{\mathrm{\text {Parameter }}} \\
\text { Expt. No }\end{array}$ & $\begin{array}{c}\text { Total } \\
\text { length } \\
\text { mm }\end{array}$ & $\begin{array}{c}\text { Useful } \\
\text { length } \\
\text { mm }\end{array}$ & $\begin{array}{c}\text { Outer } \\
\text { diameter } \\
\text { mm }\end{array}$ & $\begin{array}{c}\text { Fillet } \\
\text { radius } \\
\text { mm }\end{array}$ \\
\hline 1 & 203.0 & 78.0 & 10.0 & 3.0 \\
\hline 2 & 203.0 & 62.4 & 8.0 & 2.5 \\
\hline 3 & 203.0 & 50.0 & 6.0 & 2.0 \\
\hline 4 & 162.0 & 78.0 & 8.0 & 2.0 \\
\hline 5 & 162.0 & 62.4 & 6.0 & 3.0 \\
\hline 6 & 162.0 & 50.0 & 10.0 & 2.5 \\
\hline 7 & 130.0 & 78.0 & 6.0 & 2.5 \\
\hline 8 & 130.0 & 62.4 & 10.0 & 2.0 \\
\hline 9 & 130.0 & 50.0 & 8.0 & 3.0 \\
\hline
\end{tabular}

The aluminum solid sample shown in Table IV was prepared. Fig. 1 shows a specimen manufactured according to an L9 orthogonal array. The torsion testing was performed on a digital torsion machine of capacity $200 \mathrm{Nm}$. Each experiment was performed in three trials. As shown in fig.2, the specimen was tested until it fails.

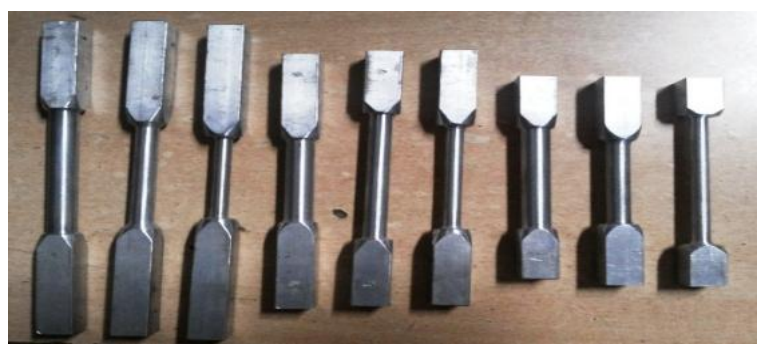

Fig. 1: Aluminium solid specimens

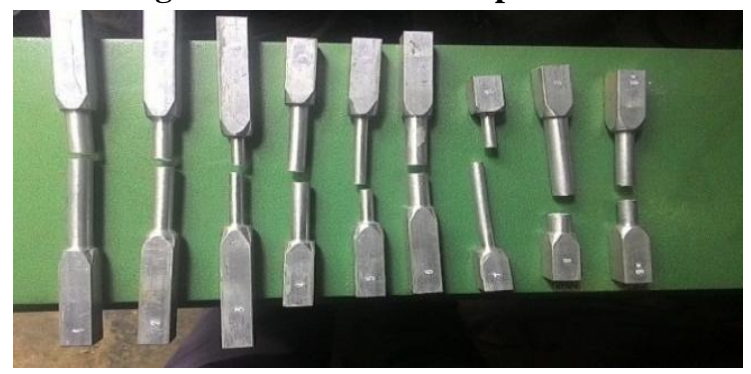

Fig. 2: Specimens after Torsion

\section{TAGUCHI'S OPTIMIZATION METHOD}

The yield shear stress value for each trial and $\mathrm{S} / \mathrm{N}$ ratio against trial numbers are shown in table $\mathrm{V}$.

Table- V: S / N ratio for each test yield stress value and test number

\begin{tabular}{|c|c|c|c|c|c|c|}
\hline \multirow{2}{*}{$\begin{array}{l}\text { Exp } \\
\text { t No. }\end{array}$} & \multicolumn{4}{|c|}{ Yield shear stress (MPa) } & \multirow{2}{*}{$\begin{array}{l}\mathrm{S} / \mathrm{N} \\
\text { ratio } \\
\text { (LB) }\end{array}$} & \multirow[t]{2}{*}{ Mean } \\
\hline & 1 & 2 & 3 & Avg. & & \\
\hline
\end{tabular}

\begin{tabular}{|c|c|c|c|c|c|c|}
\hline 1 & $\begin{array}{c}155.5 \\
6\end{array}$ & 154.52 & 153.71 & 154.51 & 43.779 & 154.51 \\
\hline 2 & $\begin{array}{c}159.4 \\
0\end{array}$ & 161.20 & 160.42 & 160.50 & 44.109 & 160.50 \\
\hline 3 & $\begin{array}{c}155.6 \\
8\end{array}$ & 156.22 & 153.83 & 154.64 & 43.786 & 154.64 \\
\hline 4 & $\begin{array}{c}159.5 \\
6\end{array}$ & 160.67 & 161.01 & 160.51 & 44.110 & 160.51 \\
\hline 5 & $\begin{array}{c}153.5 \\
5\end{array}$ & 152.95 & 151.51 & 152.58 & 43.670 & 152.58 \\
\hline 6 & $\begin{array}{c}156.3 \\
5\end{array}$ & 154.33 & 156.21 & 155.37 & 43.827 & 155.37 \\
\hline 7 & $\begin{array}{c}151.4 \\
8\end{array}$ & 152.28 & 152.08 & 152.58 & 43.670 & 152.58 \\
\hline 8 & $\begin{array}{c}159.7 \\
2\end{array}$ & 160.13 & $\begin{array}{c}158.36 \\
3\end{array}$ & 159.23 & 44.040 & 159.23 \\
\hline 9 & $\begin{array}{c}158.4 \\
4\end{array}$ & 159.98 & 159.64 & 158.84 & 44.019 & 158.84 \\
\hline
\end{tabular}

Yield shear stress is greatest for specimen dimensions with a total length $203 \mathrm{~mm}$, an effective length $62.4 \mathrm{~mm}$, an outer diameter $8 \mathrm{~mm}$, and a fillet radius $2.5 \mathrm{~mm}$. Fig. 3 shows a graph showing the effect of sample size on yield shear stress.

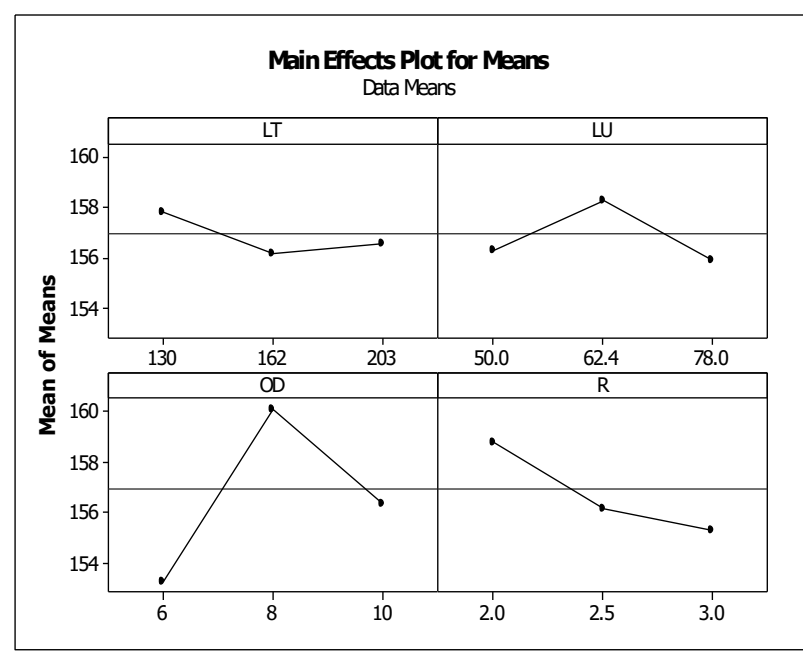

Fig. 3: Effect of specimen size on yield shear stress

After analyzing the graphs in Fig. 3, it is observed that the yield shear stress increases with increase in outer diameter and further decreases.

able -VI: Response Table for Means

\begin{tabular}{|c|c|c|c|c|}
\hline Level & Total length & $\begin{array}{c}\text { Useful } \\
\text { length }\end{array}$ & $\begin{array}{c}\text { Outer } \\
\text { diameter }\end{array}$ & $\begin{array}{c}\text { Fillet } \\
\text { radius }\end{array}$ \\
\hline 1 & 206.9 & 206.2 & 192.9 & 204.3 \\
\hline 2 & 199.3 & 204.7 & 212.9 & 202.6 \\
\hline 3 & 203.9 & 199.9 & 202.3 & 204.1 \\
\hline Delta & 7.6 & 6.2 & 20.0 & 1.6 \\
\hline Rank & 2 & 3 & 1 & 4 \\
\hline
\end{tabular}

Table VI shows the rank and delta values. This indicates that the outer diameter has the greatest effect on the yield shear stress value compared to other dimensions. The yield shear stress ANOVA is shown in Table VII and the most important parameter with the largest contribution is found. 
Table- VII: ANOVA for yield shear stress

\begin{tabular}{|c|c|c|c|c|c|}
\hline Source & DF & Seq SS & Adj SS & Adj MS & $\begin{array}{c}\text { \% } \\
\text { Contri. }\end{array}$ \\
\hline $\begin{array}{c}\text { Total } \\
\text { length }\end{array}$ & 2 & 0.801 & 0.801 & 0.401 & 0.94 \\
\hline $\begin{array}{c}\text { Useful } \\
\text { length }\end{array}$ & 2 & 3.969 & 3.969 & 1.984 & 4.70 \\
\hline $\begin{array}{c}\text { Outer } \\
\text { diameter }\end{array}$ & 2 & 67.114 & 67.114 & 33.557 & 79.49 \\
\hline $\begin{array}{c}\text { Fillet } \\
\text { radius }\end{array}$ & 2 & 12.546 & 12.546 & 6.273 & 14.85 \\
\hline Total & 8 & 84.43 & - & - & 100 \\
\hline
\end{tabular}

It is observed from table 7 that outer diameter affect the yield shear stress value significantly.

\section{GREY ANALYSIS}

The S/N ratios for each trial numbers and for three output measures are shown in table VIII.

Table -VIII: Sequence of S/N ratio

\begin{tabular}{|c|c|c|c|}
\hline $\begin{array}{c}\text { Expt. } \\
\text { No. }\end{array}$ & $\begin{array}{c}\text { Modulus of } \\
\text { rigidity }\end{array}$ & $\begin{array}{c}\text { Yield shear } \\
\text { stress }\end{array}$ & $\begin{array}{c}\text { Ultimate shear } \\
\text { stress }\end{array}$ \\
\hline 1 & -28.646 & 43.779 & 46.117 \\
\hline 2 & -28.736 & 44.109 & 46.575 \\
\hline 3 & -29.405 & 43.786 & 45.853 \\
\hline 4 & -28.890 & 44.110 & 46.249 \\
\hline 5 & -29.084 & 43.670 & 45.586 \\
\hline 6 & -28.517 & 43.827 & 46.127 \\
\hline 7 & -28.685 & 43.670 & 45.676 \\
\hline 8 & -28.445 & 44.040 & 46.120 \\
\hline 9 & -28.438 & 44.019 & 46.843 \\
\hline
\end{tabular}

\section{Normalization of S/N ratio}

In this experiment, responses such as yield shear stress are normalized using "better" properties. All normalized values are displayed in Table IX.

Table- IX: Sequence after data pre-processing

\begin{tabular}{|c|c|c|c|}
\hline Expt. No. & $\begin{array}{c}\text { Modulus } \\
\text { of rigidity }\end{array}$ & $\begin{array}{c}\text { Yield } \\
\text { shear } \\
\text { stress }\end{array}$ & $\begin{array}{c}\text { Ultimate } \\
\text { shear } \\
\text { stress }\end{array}$ \\
\hline Ref. sequence & 1.0000 & 1.0000 & 1.0000 \\
\hline \multicolumn{4}{|c|}{ Comparability sequence } \\
\hline 1 & 0.2151 & 0.2452 & 0.4229 \\
\hline 2 & 0.3075 & 0.9879 & 0.7869 \\
\hline 3 & 1.0000 & 0.2616 & 0.2124 \\
\hline 4 & 0.4672 & 0.9890 & 0.5273 \\
\hline 5 & 0.6683 & 0.0000 & 0.0000 \\
\hline 6 & 0.0812 & 0.3536 & 0.4304 \\
\hline 7 & 0.2548 & 0.0000 & 0.0719 \\
\hline 8 & 0.0067 & 0.8328 & 0.4250 \\
\hline 9 & 0.0000 & 0.7849 & 1.0000 \\
\hline
\end{tabular}

Determination of deviation sequence

It is determined using Eq. 1 as follows.

$$
\Delta_{\text {oi }}(k)=\mid x_{0}^{*}(k)-x_{i}^{*}(k)
$$

Similar procedure is followed for all 9 experiments and Deviation sequences were calculated and displayed in Table $\mathrm{X}$.

Table-X: The deviation sequences

\begin{tabular}{|l|c|c|c|}
\hline $\begin{array}{l}\text { Deviation } \\
\text { sequence }\end{array}$ & $\boldsymbol{\Delta}_{\mathbf{0 1}}(\mathbf{0 1})$ & $\boldsymbol{\Delta}_{\mathbf{0 1}}(\mathbf{0 2})$ & $\boldsymbol{\Delta}_{\mathbf{0 1}}(\mathbf{0 3})$ \\
\hline No.1, $\quad i=1$ & 0.7849 & 0.7548 & 0.5771 \\
\hline No.2, $\quad i=2$ & 0.6925 & 0.0121 & 0.2131 \\
\hline No.3, $\quad i=3$ & 0.0000 & 0.7384 & 0.7876 \\
\hline No.4, $\quad i=4$ & 0.5328 & 0.0110 & 0.4727 \\
\hline No.5, $\quad i=5$ & 0.3317 & 1.0000 & 1.0000 \\
\hline No.6, $\quad i=6$ & 0.9188 & 0.6464 & 0.5696 \\
\hline No.7, $\quad i=7$ & 0.7452 & 1.0000 & 0.9281 \\
\hline No.8, $\quad i=8$ & 0.9933 & 0.1672 & 0.5750 \\
\hline No.9, $\quad i=9$ & 1.0000 & 0.2151 & 0.0000 \\
\hline
\end{tabular}

Calculation of Grey Relational Coefficient (GRC)

Inspecting the data in Table $\mathrm{X}$ of deviation sequence. We can observe Min. and Max. Values $\left(\triangle_{\max }(k)\right.$ and

$\triangle(k))$ as follows:

$\triangle_{\max }=\triangle o_{1}(1)=\triangle o_{6}(2)=\triangle o_{1}(3)=\triangle_{07}(4)$

$=1.0000$,

$\triangle_{\min }=\Delta o_{7}(1)=\triangle o_{3}(2)=\triangle o_{7}(3)=\triangle o_{1}(4)=0.0000$

Using Table $X$, the Grey relational coefficient $\gamma\left(x_{0}^{*}(1) \cdot x_{0}^{1}(1)\right)$ can be calculated and subsequent values for all experiments are displayed in Table XI.

Grey Relational Grade (GRG)

The Grey relational grade is an average sum of the Grey relational coefficients, which is represented in table XI.

Table- XI: GRG values and Ranks

\begin{tabular}{|c|c|c|c|c|c|}
\hline $\begin{array}{c}\text { No. } \\
\text { (Comparabilit } \\
\text { y sequence) }\end{array}$ & $\begin{array}{c}\text { Modulus } \\
\text { of } \\
\text { rigidity }\end{array}$ & $\begin{array}{c}\text { Yield } \\
\text { shear } \\
\text { stress }\end{array}$ & $\begin{array}{c}\text { Ultimate } \\
\text { shear } \\
\text { stress }\end{array}$ & $\begin{array}{c}\text { Grade } \\
\text { Value }\end{array}$ & $\begin{array}{c}\text { Ran } \\
\mathbf{k}\end{array}$ \\
\hline 1 & 0.3891 & 0.3985 & 0.4642 & 0.4173 & 7 \\
\hline 2 & 0.4193 & 0.9763 & 0.7011 & 0.6989 & 1 \\
\hline 3 & 1.0000 & 0.4038 & 0.3883 & 0.5974 & 5 \\
\hline 4 & 0.4841 & 0.9784 & 0.5141 & 0.6589 & 3 \\
\hline 5 & 0.6012 & 0.3333 & 0.3333 & 0.4226 & 8 \\
\hline 6 & 0.3524 & 0.4361 & 0.4675 & 0.4187 & 6 \\
\hline 7 & 0.4015 & 0.3333 & 0.3501 & 0.3617 & 9 \\
\hline 8 & 0.3348 & 0.7494 & 0.4651 & 0.5164 & 4 \\
\hline 9 & 0.3333 & 0.6992 & 1.0000 & 0.6775 & 2 \\
\hline
\end{tabular}




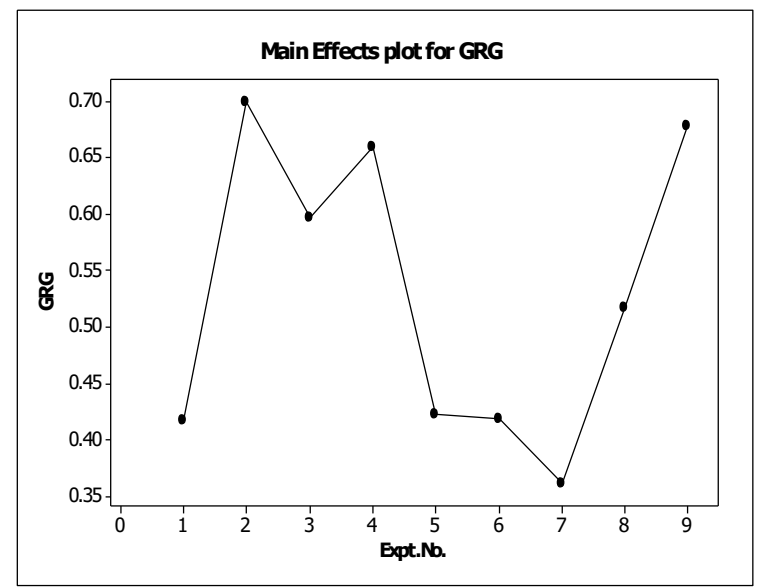

Fig. 4: Graph showing experiment number vs. each grade

\section{Selection of Optimum Parameters}

From Table XI and Fig. 4, the test number 2 is the highest gray relationship grade (0.6989), so the second number of experiments provides the optimal combination of parameters. Find the effect of each level of sample size on the GRG, as shown in Table XII. Basically, the larger the GRG, the better the corresponding output measurement. From the gray relational grade response table XIII, the optimal combination of process parameters is set in A1B3C2D3.

Table -XII: ANOVA for Grey Relational Grade

\begin{tabular}{|c|c|c|c|c|c|}
\hline $\begin{array}{c}\text { Paramete } \\
\mathbf{r}\end{array}$ & $\begin{array}{c}\text { Do } \\
\text { F }\end{array}$ & $\begin{array}{c}\text { Seq. } \\
\text { sum of } \\
\text { square }\end{array}$ & $\begin{array}{c}\text { Adj. } \\
\text { sum of } \\
\text { square }\end{array}$ & $\begin{array}{c}\text { Adj. } \\
\text { Mean } \\
\text { square }\end{array}$ & $\begin{array}{c}\text { \% } \\
\text { Contributio } \\
\mathbf{n}(\mathbf{P})\end{array}$ \\
\hline LT & 2 & 0.00817 & 0.00817 & 0.00408 & 5.99 \\
\hline LU & 2 & 0.01205 & 0.01205 & 0.00602 & 8.83 \\
\hline OD & 2 & 0.09937 & 0.09937 & 0.04968 & 72.76 \\
\hline R & 2 & 0.01696 & 0.01696 & 0.00848 & 12.42 \\
\hline Total & 8 & 0.13657 & - & - & 100 \\
\hline
\end{tabular}

Table- XIII: GRG Response table

\begin{tabular}{|c|c|c|c|c|}
\hline Levels & LT & LU & OD & R \\
\hline 1 & 0.5712 & 0.4793 & 0.4508 & 0.5058 \\
\hline 2 & 0.5001 & 0.5460 & 0.6784 & 0.4931 \\
\hline 3 & 0.5185 & 0.5645 & 0.4605 & 0.5909 \\
\hline Max-Min & 0.0711 & 0.0852 & 0.2276 & 0.0978 \\
\hline Ranking & 3 & 4 & 1 & 2 \\
\hline \multicolumn{2}{|l|}{ Total mean value of GRG is 0.5299} \\
\hline
\end{tabular}

$\mathrm{LT}=$ total length, $\mathrm{LU}=$ useful length, $\mathrm{OD}=$ outer diameter, $\mathrm{R}=$ fillet radius

\section{Calculation of GRG under optimum Parameters}

The optimal Grey relational grade $\eta_{\text {opt }}$ is predicted as below,

$$
\eta_{\text {opt }}=0.8152
$$

\section{V.CONCLUSIONS}

1. Optimal process parameters (A1, B3, C2, and D3) were used to perform the three validation experiments. Average values measured with the optimal parameters of total length, effective length, outer diameter and fillet radius are $203 \mathrm{~mm}$, $50 \mathrm{~mm}, 8 \mathrm{~mm}$ and $2 \mathrm{~mm}$, respectively. The calculated grey relational grade is 0.8152 . Table XIV summarizes the prediction and experimental results.

\section{Table -XIV: Predicted and experimental values}

\begin{tabular}{|c|c|c|c|c|}
\hline $\begin{array}{l}\text { Sr. } \\
\text { No }\end{array}$ & $\begin{array}{c}\text { Process } \\
\text { Parameters }\end{array}$ & $\begin{array}{l}\text { Initial } \\
\text { setting }\end{array}$ & $\begin{array}{c}\text { Predicted } \\
\text { Value }\end{array}$ & $\begin{array}{l}\text { Experimental } \\
\text { value }\end{array}$ \\
\hline 1 & $\begin{array}{l}\text { Optimal } \\
\text { parameter }\end{array}$ & $\begin{array}{c}\text { A1B2C2D } \\
2\end{array}$ & $\begin{array}{c}\text { A1B3C2D } \\
3\end{array}$ & A1B3C2D3 \\
\hline 2 & $\begin{array}{l}\text { Modulus of } \\
\text { rigidity }\end{array}$ & 27.34 & & 27.38 \\
\hline 3 & $\begin{array}{l}\text { Yield shear } \\
\text { stress }\end{array}$ & 160.50 & & 160.60 \\
\hline 4 & $\begin{array}{c}\text { Ultimate } \\
\text { shear stress }\end{array}$ & 213.18 & & 213.25 \\
\hline 5 & $\begin{array}{c}\text { Grey } \\
\text { Relational } \\
\text { Grade }\end{array}$ & 0.6989 & 0.8152 & 0.7091 \\
\hline 6 & remen & Frey Relati & Grade = & \\
\hline
\end{tabular}

2. The yield shear stress is found maximum for the specimen dimensions with total length $203 \mathrm{~mm}$, useful length $62.4 \mathrm{~mm}$, outer diameter $8 \mathrm{~mm}$ and fillet radius $2.5 \mathrm{~mm}$.

3. It is observed from the main effect plot that the yield shear stress increases with increasing outer diameter and then decreases further.

4 It is observed from ANOVA of yield shear stress that outer diameter affect the yield shear stress value significantly.

5. From the Grey Relational Grade of ANOVA, it is determined that the outer diameter has a greater effect on the yield shear stress due to the higher contribution of the outer diameter.

\section{ACKNOWLEDGMENT}

The author will greatly appreciate the support of the Venus instrument Ichalkaranji to support the torsion test experiment. Special thanks to Umesh Patil, Sameer Sanadi and Sandip Chougule from Venus Instruments Ichalkaranji.

\section{REFERENCES}

1. S.P.Timonshenko, D.H.Young, "Elements of strength of materials",Fifth Edition,citton educational publishing, INC.,PP.70 $-94$.

2. Stephen Timonshenko, "Strength of materials",Third Edition,CBS publishers and distributors, PP. 312-315.

3. G.E. Dieter, "The Torsion Test in Mechanical Metallurgy", Chapter 10, Third Edition, McGraw-Hill, Inc., New York, 1986.

4. R.Padmanabhan, Nuri M.Zarroug, B. J.MacDonald, M.S.J. Hashmi, [2005], "A novel adaptive control system for a custom-built tension-torsion machine", Advances in engineering software, vol.36, PP.137-146.

5. F. Yazdania, M.N. Bassima, A.G. Odeshib, [2009], "The formation of adiabatic shear bands in copper during torsion at high strain rates",Procedia Engineering , vol.1,PP.225-228.

\section{Published By:}


6. R.C. Picua,, G. Vinczeb, F. Ozturka, J.J. Graciob, F. Barlatb,c, A.M. Maniattya,[2005], "Strain rate sensitivity of the commercial aluminum alloy AA5182-O",Materials Science and Engineering Advances,vol.390, PP.334-343.

7. N.M Zarroug, R Padmanabhan, B.J MacDonald, P Young, M.S.J Hashmi, [2003], "Mild steel (En8) rod tests under combined tension-torsion loading”, Journal of Materials Processing Technology, vol. 143-144, PP.807-813.

8. Jose Divo Bressan,Ricardo Kirchhof Unfer, [2006], "Construction and validation tests of a torsion test machine", Journal of Materials Processing Technology, vol.179, PP.23-29.

9. A. Graber, K. Pohlandt, K. Lange, [1989], “A New Approach to the Torsion Test for Determining Flow Curves", CIRP Annals Manufacturing Technology, vol. 38, PP.223-226.

10. Han-Chin Wu, Zhiyou Xu, Paul T Wang, [1997], "Torsion test of aluminum in the large strain range", International Journal of Plasticity, vol.13,PP.873-892.

11. S.L. Semiatin, N. Frey, N.D. Walker, J.J. Jonas,[1986], "Effect of deformation heating and strain rate sensitivity on flow localization during the torsion testing of 6061 aluminum", Acta Metallurgica, vol 34, PP.167-176.

12. M. Yeganeh,R. Naghdabadi, [2006] "Axial effects investigation in fixed-end circular bars under torsion with a finite deformation mode based on logarithmic strain", International Journal of Mechanical Sciences, vol.48, PP.75-84

13. Dabiao Liu, Yuming He, Xutao Tang, Huaming Ding, Peng $\mathrm{Hu},[2012]$,"Size effects in the torsion of microscale copper wires: Experiment and analysis", Scripta Materialia vol.66,PP.406-409.

14. J.R. Klepaczko, [1994], "An experimental technique for shear testing at high and very high strain rates. The case of a mild steel",International Journal of Impact Engineering, vol.15,PP.25-39.

15. Pavel A. ,Mossakovsky Fedor K., Antonov Lilia A., Kostyreva,[2011], " Investigation of Failure Criterion in Dynamic Torsion Tests with Solid Cylindrical Specimens", 8th European LS-DYNA Users Conference, PP.1423-1430.

16. Karl Ulrich, Warren Seering, [1988], "Computation and conceptua design",Robotics and Computer-Integrated Manufacturing, vol.4, PP.309-315.

17. Bahman Mirzakhani, Shahin Khoddam, Hossein Arabi, Mohammad Taghi Salehi, Seyed Hossein Seyedein, Mohammad Reza Aboutalebi,[2010], "Influence of Specimen Geometry of Hot Torsion Test on Temperature Distribution During Reheating Treatment of API-X70", Journal of Iron and Steel Research, International vol.17,PP.34-39.

18. F. Berto, M. Elices, P. Lazzarin, M. Zappalorto, [2012],"Fracture behaviour of notched round bars made of PMMA subjected to torsion at room temperature", Engineering Fracture Mechanics, vol. 90,PP. 143-160.

19. Jan Dvorak , [1967] , "The state of stress in a thick plate loaded by torsion and bending and containing a hole", Nuclear Engineering and Design, vol.5, PP. 63-70.

20. Utpal Borah, Diptimayee Samantaray, Shaju K. Albert, A. K. Bhadur ,T. Jayakumar,[2013], "Thermo-Mechanical Axial-Torsion Testing to Assess Workability Modeling Using Finite Element Method and Experimental Validation",International Journal of Metallurgical Engineering, vol.2, PP.214-220.

21. Rao V. (2011) "Advanced Modeling and Optimization of Manufacturing Processes" International Research and Development 1, PP.1-380.

22. Eldon Y. (1994) "Artificial neural networks and their business applications" Information \& Management 27, PP.303-313.

23. Patil G., Inamdar K. (2014) "Optimization of Casting Process Parameters using Taguchi Method" International Journal of Engineering Development and Research 2, 2, PP.2506-2511.

24. Kulkarni A., Malagi R., Pol A. and Kittur J. (2014)" Parameter Optimization of No Bake Core Making Process by Using Taguchi Method" International Journal of Engineering Research 3, 7, PP.426-429.

25. Refaie and Li M. (2008) "Alpha Risk of Taguchi Method with L18 Array for NTB Type QCH by Simulation" Proceedings of the World Congress on Engineering 2, PP.3-7.

26. Kamaruddin S., Khan Z. and Wan K. (2004) "The use of the taguchi method in determining the optimum plastic injection moulding parameters for the production of a consumer product" Jurnal Mekanikal 18, PP.98-110.

27. Kacker R., Lagergren E. and Filliben J. (1991) "Taguchi Vs Orthogonal Arrays Are Classical Designs of Experiments" Journal of
Research of the National Institute of Standards and Technology 96, 5 , PP.577-591.

28. Unal R. and Dean E. (1991) "Taguchi approach to design optimization for quality and cost: an overview" Annual Conference of the International Society of Parametric Analysts 1, PP.1-10.

29. Antony J. and Antony F. (2001) "Teaching the Taguchi method to industrial engineers" Work Study 50, 4, PP.141-149

\section{AUTHORS PROFILE}

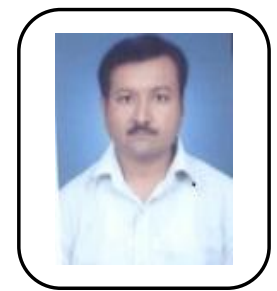

Prof. Rajkumar D. Patil has completed M.E. in Mechanical Engineering in product design and development and working as assistant professor in D.K.T.E.'s Textile and Engineering Institute, Ichalkaranji, Maharashtra-416115, India. He has a 12 years of teaching and 4 years of industrial experience. He has published more than 12 papers in international journals and conferences. He has published a book in torsion testing.

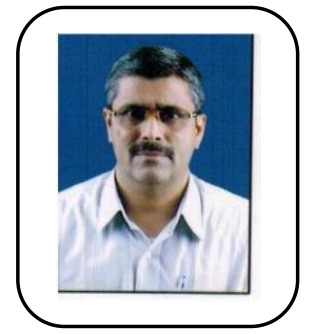

Prof. Purushottam N. Gore has been serving as Associate Professor in Mechanical Engineering department of D.K.T.E.'s Textile and Engineering Institute, Ichalkaranji, Maharashtra-416115, India. He has 25 years of teaching and 5 years of industrial experience. He has got best teacher award in 2007-2008. He has published more than 20 papers in international journals and conferences. He has published a book in torsion testing. 